\title{
Nathaniel William Taylor and Thomas Reid: Scottish common-sense philosophy's impact upon the formation of New Haven theology in Antebellum America
}

\author{
Michael W. DeLashmutt
}

No. 4 The Square Department of Theology, University of Glasgow, Glasgow G12 8QQ

m.delashmutt@arts.gla.ac.uk

\begin{abstract}
This paper will examine the relationship between Scottish common-sense philosophy and the formation of New Haven Theology. It will be illustrated that Nathaniel William Taylor's adaptations of orthodox Calvinism (particularly the doctrines of election and predestination and total depravity) relied heavily upon the principles of common-sense philosophy found in the work of Thomas Reid. Furthermore, it will be argued that Taylor's adaptation of Calvinism was a necessary accommodation to the phenomenon of mass conversion and evangelism during the Second Great Awakening.
\end{abstract}

\section{Introduction}

In antebellum America, the primacy of traditional Reformed (Calvinist) theology, which for nearly 200 years had been the cornerstone of religious life in the Protestant New World, was challenged by revivalism and experiential piety, which called into question the hallmark Calvinist doctrines of total depravity and election and predestination. Either Reformed theology would need to reform yet again, and adapt to the contemporary religious landscape, or it would run the risk of obsolescence in the face of the emerging popularity of non-traditional forms of Protestant doctrine and experience. New Haven theology, as epitomised by the work of Nathaniel William Taylor, synthesised traditional orthodox Calvinism with the evangelistic concerns surrounding the phenomenon of mass conversions during the time of the Second Great Awakening, by appropriating a theological methodology which relied heavily upon Scottish common-sense philosophy. ${ }^{1}$ Taylor's innovative approach to the doctrine of total depravity and rational approach to the doctrine of election and predestination bore a strong resemblance to the

${ }^{1}$ It should be noted that 'common sense' is not, as in the modern parlance, merely the antithesis of folly. Rather, it is a philosophy which gives weight to the universal availability and reliability of sense perception. 
philosophical work of the eighteenth-century Scottish philosopher Thomas Reid. Both Reid and Taylor believed in the need for philosophy and theology to be easily understood by the common person and to be grounded in the legitimacy of personal experience. Furthermore, both Reid and Taylor possessed a high view of anthropology, which manifested itself chiefly in their position on the moral capacity of humankind.

\section{Scotland's philosophical trajectory}

Glasgow and moral philosophy: Hutcheson, Smith, and Reid

In eighteenth century Glasgow, Hutcheson, Smith and Reid were the preeminent figures in the University's moral philosophy programme. Francis Hutcheson $^{2}$ was influenced by the moral philosophy of Shaftesberry, and from his example developed a concept known as 'moral sense', which placed the onus of moral construction upon the subject's personal feelings and dispositions towards actions. At the time he was judged an Epicurean, whose approach to morality was understood as being overly reliant upon emotion at the expense of reason or rationality. Furthermore, his high view of anthropology as evidenced in his belief in human positive moral agency, evoked censure of his work from the Glasgow Presbytery. ${ }^{3}$ According to the Presbytery, unregenerate human capacity for moral good contradicted the Calvinist doctrine of total depravity. His opposition at the time notwithstanding, Hutcheson's theories were adopted in part by his pupil Adam Smith, ${ }^{4}$ who was often a severe critic of his professor's work. Nonetheless, at least in one regard Smith followed in Hutcheson's footsteps by continuing to place the onus of moral construction upon the human subject although Smith's moral philosophy was much more Stoic and rational in its orientation than was the Epicurean and emotive 'moral sense' of his predecessor. For Smith it was the human will (and not human emotions) which became the centre of the moral universe. Accordingly, it was the subject's wilful conformity to social mores which made the subject a reliable moral agent. As long as an individual willed to do that which would not harm the other, that individual would be considered moral. Both Smith and Hutcheson adhered to the metaphysical idealism of Hume, and as such denied the subject's direct access to the objective world. In such a philosophy, the subject is placed precariously between two conflicting domains of reality. Although the subject is understood to be able to correctly judge the good,

2 b. 1694, d. 1746, taught philosophy at Glasgow University from 1729.

3 Sydney Ahlstrom, 'The Scottish Philosophy and American Theology', Church History 24 (1955): 259.

${ }^{4}$ b. 1723, d. 1790, professor of moral philosophy at Glasgow University 1751-63. 
he or she has no reliable or direct access to the very world which was to be judged. This tension was resolved in the common-sense philosophy ${ }^{5}$ of Reid, which affirmed both the moral and the perceptual capacity of the subject.

Thomas Reid: common sense par excellence. Thomas Reid (1710-96) is often considered to be the sine qua non of eighteenth-century Scottish common-sense thought. Reid was a clergyman's son from Aberdeenshire. In his early career, he worked as a session clerk for the Kirk, and later was accepted as Regent of Philosophy at King's College, Aberdeen. In 1764, Reid assumed Adam Smith's chair as professor of Moral Philosophy at Glasgow University. Reid represented the logical continuation of Glasgow's moral philosophy trajectory. Like his forebears, Reid held to a high view of human moral capacity, and of the universal ability to choose that which was morally responsible. But Reid's chief departure from Hutcheson and Smith centred on his personal disdain for the philosophy of David Hume. ${ }^{6}$ Hume's metaphysical assertions, which denied the subject direct access to the objective world, were understood by Reid to be complete and utter lunacy. Reid's common-sense approach to philosophy affirmed the reliability of the senses and denounced idealism as a philosophy which promoted an unnecessarily complex metaphysic. His opposition to Hume's Treatise on Human Nature is no more clearly stated than in Reid's principal philosophical work, the Inquiry into the Human Mind on the Principles of Common Sense. Through Inquiry, Reid creates a forceful apologetic defending the reliability of subjective experience in contradiction to Hume's claims of radical scepticism. At the heart of this debate on metaphysics, was the question of how relevant psychology was to

${ }^{5}$ Although Reid's common-sense philosophy was incredibly innovative; to say that common-sense was first invented in Scotland or that before the eighteenth-century Scottish Enlightenment no one had ever exhibited a penchant for common sense, would ignore the principle common-sense texts of Aristotle, Thomas Aquinas, the English revolutionary Richard Hooker, or even Jean-Jacques Rousseau whose Creed of a Savoyard Priest lauds basic common-sense axioms. Additionally, outside of 'Faculties of Philosophy', common-sense methodologies were exhibited by Francis Bacon and Isaac Newton, whose dispositions towards and approaches to the sciences were the quintessence of common sense. Ahlstrom, 'The Scottish Philosophy and American Theology', 259.

${ }^{6}$ It should be said that Reid's philosophy, though reliant upon common-sense, and seemingly antagonistic to Idealist philosophy, is not against reason. Reason, in Reid, is based upon reality. 'It is a common observation that it is unreasonable to require demonstration for things which do not admit of it. It is no less unreasonable to require reasoning of any kind for things which are known without reasoning, all reasoning must be grounded upon truths which are known without reasoning.' Thomas Reid, 'Essays' VII 3.3 in Sir William Hamilton, ed., The Works of Thomas Reid (Edinburgh: Maclachlan and Stewart, 1863), 1:481-2. 
the creation of epistemology. Reid, unlike Hume, based his philosophy upon the belief that objects and others were as they appeared to be. ${ }^{7}$ According to Reid, perceptions revealed reliable information about objects and persons, meaning that the underlying nature of the world was directly knowable by the mind. ${ }^{8}$ Put succinctly, Reid's common-sense philosophy held as its central tenet the belief that human sensory capacity was reliable and profitable for creating a map of the world, from which one could confidently navigate through life. Reid believed that it was simply self-evident and 'God-given' that all people were created with, and readily exercised, the capacity to know the world directly. ${ }^{9}$ The universal availability of reliable sensory perception meant that it was not merely those who were trained in the art of reason who could understand the world and execute proper moral choices. ${ }^{10}$ In fact, the only caveat for this universal principle was the exclusion of lunatics and philosophers; who in Reid's witty repartee were both considered to be capable of willingly doubting the existence of the world around them! ${ }^{11}$

Reid's philosophy is based upon a series of principles, often referred to as 'first principles' that are descriptive axioms upon which our experience of the world is based. Though there are quite literally dozens of lists in his work that numerate these principles, one of the more concise inventories of common sense is found in the fifth book of his Essays. Twelve of these principals are: (1) a belief in the existence of all things of which I am conscious; (2) that my thoughts are my own; (3) that my memories are

7 This sentiment seems to reflect what I consider to be proto-phenomenological philosophy which posits that objects are knowable in themselves by the human senses.

8 Reid commonly enjoyed using the foolishness of other philosophers as the object of his own ridicule. For example, see 'Essays' II 8'.

9 According to Reid, reliable sensory knowledge of the world is given to humankind by the 'Supreme Being'. The capacity for this knowledge is given equally to all, from 'the most ignorant to the most learned'. Reid, 'Essays' II 5 in Hamilton, ed., The Works of Thomas Reid, 1:260.

10 'I believe no man of a sound mind ever doubted of the real existence of the operations of mind, of which he is conscious. Nor is it to be doubted that, by the faculties which God has given us, we can conceive things that are absent, as well as perceive those that are within the reach of our sense; and that such conceptions may be more or less distinct, and more or less lively and strong'. Reid, 'Essays' II 14 in Hamilton, ed., The Works of Thomas Reid, 1:298.

${ }^{11}$ In his third rule for perception, Reid asserts that it is not, "by a train of reasoning and argumentation that we come to be convinced of the existence of what we perceive; we ask no argument for the existence of the object, but we perceive it; perception commands our belief upon its own authority, and disdains to rest its authority upon any reasoning whatsoever.' Reid, 'Essays' II 5 in Hamilton, ed., The Works of Thomas Reid, $1: 259$. 
reliable; (4) that my existence is self-constant; (5) that things really exist which I perceive by my senses; (6) that I have 'some degree' of power over my actions and the determination of my free will; (7) that my natural capacity to distinguish truth from error is reliable; (8) that the other person has an intelligent inner life; (9) that actions as well as words indicate thoughts in the mind of myself and the other; (10) that testimony and personal opinion are matters of regard; (11) that there are events which are self-evident; and lastly (12) that nature will remain phenomenological self-referential: things will be as they have been in similar situations. ${ }^{12}$ Reid, through enumerating these principles, makes a case for the capacity of the common person to judge their world, their life, and their history. The subject is no longer lost in a Cartesian mist of self-doubt, and is able to emerge from the fog with dignity and determinability. The priority which Reid places upon the individual is also reflected in his theological work.

Excurses: Reid's theological writings. In addition to teaching classes on moral philosophy while at Glasgow, Reid also lectured on natural theology. Despite the fact that Reid himself did not produce any sizeable works that are considered purely theological, recent scholarship has created an edited volume comprised of notes taken by students of Reid during his theological lectures. ${ }^{13}$ This manuscript sheds valuable light upon Reid's thinking on theological matters, and although these lectures likely had nominal direct bearing upon the theological landscape of antebellum America, they confirm the legitimacy of much of the theological thought in the Protestant New World; which as I will demonstrate below, was constructed in part from Reidian principles.

For the sake of brevity, we will limit our investigation of Reid's theology to his position on total depravity. Reid departed from orthodox Calvinism's belief that the universal and total contamination of sin resulted in human ineptitude for the good. In keeping with his high view of anthropology, in his lectures On Natural Theology Reid clearly states that sin or the disposition to sin, like so many other behaviours, is a learned rather than inherited trait. ${ }^{14}$ This implies that from birth, humans possess the capacity for positive moral

12 Reid, 'Essays' V 5-6 in Hamilton, ed., The Works of Thomas Reid, 1:442-51.

13 Elmer H. Duncan and William R. Eakin, eds., Thomas Reid's Lectures on Natural Theology (1780) (Washington, DC: University Press of America, 1981).

14 'Men [sic] are led by natural instinct to imitate the actions of those around them. Now this has an evident relation to society. . . even those affections which we call malevolent show that we were intended for society as without it, we could have no occasion to exercise them.' Reid Lecture 18 in Duncan and Eakin, ed., On Natural Theology, 46. 
agency. Any failure in this capacity is not a predestined fact; it is simply a result of poor socialisation. ${ }^{15}$ Quoting from Reid:

We can have no greater degree of testimony for the truth of anything than the testimony of our senses and of these qualities which God has given us; by these we discover that some propositions are true and others false... now our judgment of right and wrong is as certain as our judgment of true and false and to suppose that the Supreme Being to have another standard of measuring them than we... is as absurd as to say that he has a different conception of what is true and false... ${ }^{16}$

As we shall see below, this is precisely the sentiment towards sinfulness adopted and developed by the New Haven Divines and Nathaniel William Taylor in nineteenth-century antebellum America.

\section{North American religious life}

\section{Calvinism}

We now move our attention from the time, place, and work of Thomas Reid, to the main theatre of our discussion: the Protestant New World of the American Northeast. As with Reid in eighteenth-century Scotland, the early religious climate of the fledgling American nation was principally Reformed (Calvinist). Reformed theology relies heavily upon the writings of both John Calvin and the Westminster Divines. Though it is far beyond the scope of this essay to exhaustively consider the intricacies of Reformed theology, the brief introduction to the doctrines of original sin/total depravity and election and predestination provided below, will illuminate our subsequent discussion of how changes to these doctrines occurred in the hands of the New Haven Divines.

Original sin/total depravity. According to Calvin's Institutes of the Christian Religion, humankind suffers the consequence of sin because of Adam's original departure from the will of God. The fall of Adam, 'effaced' the 'heavenly image in man', and as a result, Adam, and ergo humankind, were

15 Obviously, this sentiment reeks of Enlightenment educational sensibilities, which sought to provide proper culture and education to individuals, so as to create a stable state. Yet, in Reid this disposition is used to supersede the traditional reformed view of moral depravity. As we shall see below, this is precisely the direction which was taken by Nathaniel William Taylor in regards to human sinfulness.

${ }^{16}$ Reid Lecture 78 in Duncan and Eakin, eds., On Natural Theology, 97; Reid Lecture 84 in Duncan and Eakin, eds., On Natural Theology, 99. 
punished by:

a withdrawal of the ornaments in which he had been arrayed . . . wisdom, virtue, justice, truth, and holiness, and ... in their place... blindness, impotence, vanity, impurity, and unrighteousness, but he [Adam] involved his posterity also, and plunged them in the same wretchedness. ${ }^{17}$

As a basis for his stance on original sin, Calvin reiterated Augustine's position on the same, by asserting that humankind is, 'not corrupted by acquired wickedness, but bring[s] an innate corruption from the very womb'. ${ }^{18}$ Because original sin is transmitted through heredity, all people (as ancestors of Adam) are subsequently completely depraved: 'All of us, therefore, descending from an impure seed, come into the world tainted with the contagion of sin. Nay, before we behold the light of the sun we are in God's sight defiled and polluted.' ${ }^{19}$

Election and predestination. The doctrine of election and predestination, as a central tenet of Calvinism, is likely even more contentious and more unsavory to its opponents than is Calvin's doctrine of total depravity. Calvin himself admits its complexities stating that: 'To many this seems a perplexing subject, because they deem it most incongruous that of the great body of mankind some should be predestinated [sic] to salvation, and others to destruction., 20

At the heart of the matter, the doctrine of election and predestination implies that some of humankind have been selected by God for eternal reward, whereas others have been predestined for eternal damnation. For Calvin, this doctrine is a necessary means of maintaining or protecting the absolute glory of God. ${ }^{21}$ In this system, God alone has the power to dispense salvation, and no action of a single person could impede his or her divinely predestined fate. ${ }^{22}$ In orthodox Calvinism it is God's complete sovereignty

17 John Calvin, Institutes of the Christian Religion, II.1.5.

${ }_{18}$ Calvin, Institutes of the Christian Religion, II.1.5.

19 Calvin, Institutes of the Christian Religion, II.1.5.

${ }^{20}$ Calvin, Institutes of the Christian Religion, III.21.1.

21 'It is plain how greatly ignorance of this principle detracts from the glory of God, and impairs true humility.' Calvin, Institutes of the Christian Religion, III.21.1.

22 'All things always were, and ever continue, under his eye; that to his knowledge there is no past or future, but all things are present, and indeed so present, that it is not merely the idea of them that is before him, (as those objects are which we retain in our memory,) but that he truly sees and contemplates them as actually under his immediate inspection.' Calvin, Institutes of the Christion Religion, III.21.1.5. 
and foreknowledge, and not his prescience, by which the elect are chosen. Quoting again from Calvin, it is by 'the eternal decree of God, by which he determined with himself whatever he wished to happen with regard to every man [sic]', which implies that 'all are not created on equal terms, but some are preordained to eternal life, others to eternal damnation; and, accordingly, as each has been created for one or other of these ends, we say that he [sic] has been predestinated to life or to death'. ${ }^{23}$

It becomes clear from the above, that Calvinism promotes an extremely elevated view of God's sovereignty (at times at the cost of his benevolence), and an extremely low view of anthropology (at times at the cost of moral agency). Even in this brief summary, one can see potential areas of conflict between Calvinism and common-sense philosophy - particularly with regard to moral capacity. Although in eighteenth-century Scotland this conflict resulted in the official censure of the moral philosophy of Hutcheson; in nineteenth-century America (in the hands of the New Haven Divines) Scottish common-sense philosophy and its high anthropology were seen as the saviours of what was considered to be the spirit of Calvinist Orthodoxy.

\section{Scottish diaspora}

Calvin's theology played an enormous role in the development of North American Protestant Christianity. Early American Protestants were directly related to Calvinist Puritan sects in sixteenth- and seventeenth-century Britain. English puritans, who were theologically Reformed, escaped persecution in their home country by fleeing to Holland and then to the New World in the seventeenth century. Later, a diaspora of Presbyterian Scots flooded the Americas in the eighteenth century and beyond, bringing with them not only their Reformed theological tradition, but also their emerging philosophies. The Scottish-American diaspora contributed to the already Reformed theological climate of the New World. Many historians have commented on the undeniable influence of Scottish thought upon the formation of the new American nation. The American Declaration of Independence, the writings of Thomas Jefferson, Benjamin Franklin, and the American Constitution, reflect marked parallels with Scottish common-sense philosophy.

In the world of politics, it would seem that Scottish common-sense philosophy was employed by the fledgling nation to justify the war against Britain and also as a means of outlining new principles of social order in 
the absence of the crown. ${ }^{24}$ But from a theological perspective, the principal use of Scottish common-sense philosophy was for restoring the place of Christianity in absence of an established church. To this end, what made Scottish philosophical thought so unique and so useful in the emerging American religious situation, was its ability to facilitate religious thinking apart from the Old World church, and the Old World philosophical systems. On the one hand, eighteenth- and nineteenth-century American theology and philosophy represented a Christianised form of European Enlightenment thinking, in which European ideals were adopted and integrated into the American ethos. Yet, on the other hand, through their adaptation by theologians, the Enlightenment ideals were so Christianised and so 'Americanised', that the American appropriation of the European Enlightenment became an entirely distinct phenomenon. ${ }^{25}$

In the theological world of eighteenth- and nineteenth-century America, it is likely that the first emissary of Scottish thought was the conservative theologian John Witherspoon (1723-94), who left his native Scotland in 1768 to become the president of what was then called the College of New Jersey in Princeton. ${ }^{26}$ Although early in his career as college president, Witherspoon chose to favour the English philosophy of Berkeley and Locke, over the common-sense philosophy of his fellow countryman Thomas Reid, it quickly became clear to Witherspoon that in the American religious situation (in which Deism, Unitarianism, and French Enlightenment ideology were in ascendancy, whereas his own form of orthodox Calvinism was in decline) the philosophical work of Thomas Reid was particularly well suited to fortify the weakening bulwark of Calvinist orthodoxy against the creeping tide of secularism which threatened the church.

Although Calvinism was challenged by Unitarianism and Deism, at the heart of its decline was the fact that Calvinism seemed to function more robustly as a state religion than it did as a non-enforced religious philosophy. Without the pressures of a government to mandate a reformed theological system, or an institutional church to mediate the means of grace to the elect, Calvinism lost its appeal to the majority of Americans. Soon after

${ }^{24}$ Mark A. Noll, A History of Christianity in the United States and Canada (Grand Rapids, MI: William B. Eerdmans Publishing Company, 1992), 233.

25 'The philosophical doubts of David Hume and the sneers at religion from French savant Voltaire found little sympathy in the new nation. Yet important principles of the enlightenment, as these had been refined by other Europeans of the eighteenth century, came to exert near-universal domination in America.' Noll, A History of Christianity in the United States and Canada, 154.

26 Ahlstrom, 'The Scottish Philosophy and American Theology', 261. 
Witherspoon's time, by the early nineteenth century, America was far more secular a nation than it was a Christian, much less a Calvinist one. ${ }^{27}$ The closed sectarian policies of many of the early Protestant groups in the New World during the seventeenth and eighteenth centuries meant that horizontal growth through proselytising seldom occurred (the Great Awakening aside). When combined with a vertical or genetic decline in the church's demographic, caused by the strict pietistic lifestyles of many of the reformed sects - which compelled younger generations to flee the austere faith of their parents - it became clear that Reformed Christianity was in need of some type of revolutionary change. It is most likely that Witherspoon implemented Scottish common-sense philosophy because of the emphasis it placed upon the individual's capacity to know and judge the truth. Whereas, in the Old World, Reformed confessions of faith were encouraged through means of juridical legislation; in the New World and in the absence of a state religion, it was the individual's own sense which needed to be compelled to faith through logically reasonable arguments. ${ }^{28}$

Following Witherspoon's promotion of Reid's writing, in a very short time the message of Scottish philosophy was carried to 'seminaries and churches all over the country', ${ }^{29}$ through the work of the great Princeton divine Charles Hodge (1797-1878) and other Princeton academics, alumni, and affiliates. Yet it wasn't Hodge and the College of New Jersey which made the most use of Scottish common-sense philosophy. Rather, it was 130 miles northeast of Princeton in New Haven, Connecticut - the seat of Jonathon Edward's theological legacy - that we find Scottish common-sense philosophy's most significant theological impact.

27 'If the colonial situation worked for the acceptance of revivalism, the situation under religious freedom in the new nation [during the Antebellum period] tended to make it imperative.' It was noted by Professor Winfred Garrison that, 'with $90 \%$ of the population outside the churches, the task of organised religion could not be limited to encouraging "Christian nurture". . . in Christian families, or to ministering to old members as they moved to new places farther west. It had to be directed toward that $90 \%$. What they needed first was not nurture or edification, but radical conversion ... [and since they] followed no chiefs... they had to be brought in one by one.' Winfred E. Garrison, 'Characteristics of American Organised Religion', Annals of the American Academy of Political and Social Science, CCLVI (March 1948), 19, in Sidney E. Mead, The Lively Experiment: The Shaping of Christianity in America (London: Harper \& Row, 1976), 122.

28 Noll, A History of Christianity in the United States and Canada, 167.

29 Ahlstrom, 'The Scottish Philosophy and American Theology', 262. 
The history of New Haven

In order to appreciate the gravity of the changes to Calvinism that were put into effect by Nathaniel William Taylor, it will be necessary to attend to a brief and illustrative survey of Taylor's predecessors at Yale: Jonathon Edwards and Timothy Dwight.

Jonathon Edwards. Jonathon Edwards (1703-58) is considered by some to have been the greatest Calvinist theologian/philosopher in antebellum America, and possibly the greatest in the history of America as a whole. Edwards was born in 1703 and raised in North Hampton, Massachusetts. He attended Yale College in 1716, graduated in 1720, and continued his studies at the college until 1722. From early 1722 to 1723 , Edwards served as a minister of a Scottish Presbyterian church in New York, but he left this position towards the middle of 1723, to continue his graduate studies at Yale College. After completing his Master's degree, he agreed to remain at Yale for two years as a tutor in theology. He left his post in 1726 due to illness, and later that year accepted a position as an assistant minister under his grandfather, Solomon Stoddard, head minister of a Congregational Church in Edwards' hometown of Northampton. When Stoddard died, Edwards took over his grandfather's ministry, and led the church for many years. Under Edwards' care, the church experienced a tremendous revival from 1734 through 1739, which became known as the Great Awakening. He was relieved of his charge in 1750 and died in 1758, mere months before he was scheduled to assume a post as the new president of the College of New Jersey in Princeton.

When one looks at Edward's preaching, one does not readily equate it with the stuff of modern day revivalism; it lacked much of the 'razzamatazz' that contemporary revivalists are pejoratively known for. The meat of Edwards' message is what came to be known as old-school Calvinism, and as such he emphasised the universal and total depravity of humankind and the serious nature of sin. It is clear in Edwards' theology that his preaching would have been aimed solely at the elect, and it is obvious in his message that his heart was deeply concerned for their eventual conversion.

The theocentric emphasis of Calvinism found tremendous expression through the writings and sermons of Edwards, who offered the best of his skills to ensure that the importance of 'God in everything' was communicated through his life and work. As a result, Edwards denied that humans would have any ability to choose God simply out of a desire to escape the jaws of hell, a topic which he is most famously known for in his sermon Sinners in the Hands of an Angry God. According to Edwards (following Calvin), God alone makes the decision of who is elect and who is not; assuming that 
one could thwart this divine plan would be complete hubris. Again, as in Calvin, Edwards asserts that humankind is ultimately unable to choose God or choose morality because of the totally corrupt state of the will. ${ }^{30}$ Edwards' Freedom of the Will does offer limited freedom of choice to the individual (in regards to conversion) but nothing of the sort that eventually develops in the work Edwards' grandson Timothy Dwight ${ }^{31}$ and in turn Dwight's chief pupil Nathaniel William Taylor.

Timothy Dwight. Timothy Dwight (1752-1817) as Jonathon Edward's grandson rightly saw himself as the inheritor of Edwardsian orthodoxy at Yale Divinity School. He became the president of his Alma matter in 1795 and held this position until his death. While president of Yale, Dwight's revivalistic preaching affected at least one third of the university's student population, resulting in a very fervent religious environment at the school. He was renowned for his vigorous defence of Calvinist orthodoxy against what at the turn of the nineteenth century was considered to be the onslaught of Unitarianism and Deist philosophy. ${ }^{32}$ Like so many apologists in his day, as Dwight moved to defend Edwards and Calvin from these emerging philosophies, he ultimately altered the very orthodoxy which he sought to protect. In the case of Edwards' theology, Dwight underplayed Edwards' notion of divine responsibility for sin, and replaced it with his own belief that the sinner was to blame for his or her own sinfulness; thus stressing the sinner's role in personal salvation and in the need for repentance. ${ }^{33}$ Towards the end of Dwight's tenure as president, the threat from Unitarianism and Deism waned and a new challenge to Orthodoxy emerged in the form of Methodist revivalism. The new challenge required a new Yale divine to rise to the occasion.

The emergence of Methodism. Although at the time of Jonathan Edwards the Protestant demographic in antebellum America was favourable to Congregationalists and Presbyterians, as has been stated above by the midnineteenth century the reformed groups were in decline. Towards the end of Dwight's tenure, Methodism was by far the most popular denomination,

${ }^{30}$ Leo P. Hirrel, Children of Wrath: New School Calvinism and Antebellum Reform (Lexington: University Press of Kentucky, 1998), 14.

31 Dwight was not a substantial figure in the development of New Haven theology; he was merely a transitional character. It has been noted though, that Dwight's work plainly reflected the 'impact of wide reading in Scottish philosophers.' Ahlstrom, 'The Scottish Philosophy and American Theology,' 263.

32 Conrad Cherry. 'Nature and the Republic: The New Haven theology', The New England Quarterly 51 (1978): 511.

33 Hirrel, Children of Wrath: New School Calvinism and Antebellum Reform, 27. 
making up nearly 30 per cent of Protestant America. ${ }^{34}$ Although the Reformed theology of New Haven and the Methodist theology of revivalism differed significantly, ${ }^{35}$ we shall see that the reaction of the former to the latter was more praxological than it was theological. New Haven theology reinvented orthodox Calvinism in order to defend the practice of mass evangelism and personal conversion - the very hallmarks of (Methodist) experiential piety during the time of the Second Great Awakening. ${ }^{36}$ In this setting it became clear to the Yale divines that the doctrines of election and predestination and total depravity needed to adapt to the reality of revival, and the new found popularity of experiential piety. Fortunately, through Witherspoon's introduction of the work of Thomas Reid into theological world of the antebellum era, New Haven Divines had ready-athand the philosophical tools they would need to justify and explain such phenomena.

\section{Nathaniel William Taylor}

Dwight's prized student, Nathaniel William Taylor, graduated from Yale Divinity School in 1807. Shortly following graduation, Taylor went on to tutor the Van Rensselaer family in Albany, but this sojourn into public tutoring was short-lived, and he quickly returned to New Haven to resume

34 In 1776, Congregationalists made up 20 per cent of the Christian populations, with Presbyterians trailing closely behind with 19 per cent. By the 1850s, this had changed dramatically with Methodists holding 30 per cent, followed closely by Baptists at 20 per cent. Congregationalists and Presbyterians comprised only 15 per cent of the population combined. Noll, A History of Christianity in the United States and Canada, 153.

35 Methodist revivalistic theology, compared to the orthodox Calvinism of Edwards and Dwight, placed a strong emphasis upon human capacity to respond to divine grace. Methodism had a high view of anthropology, resulting in a theology that affirmed humanity's ability to freely choose the moral or theological good. As mentioned above, Edwards preached only to those who would respond to his message, as predetermined by divine election. This is in contrast to the practices of Methodist revivalists such as Francis Asbury who preached to all people, believing that anyone could respond positively to God's free offer of salvation. According to Methodist theology, God's desire that 'none should perish', overweighs the historical concept of election and predestination.

36 It was the spirit of revivalism to require the communicant to make their conversion decision at the moment of evangelistic proclamation. This quote from the nineteenthcentury revivalist Billy Sunday epitomises a revivalist's belief that the individual was in control of their eternal fate: 'You are going to live forever in heaven, or you are going to live forever in hell. There's no other place - just the two. It is for you to decide. It's up to you and you must decide now.' Billy Sunday in William G. McLoughlin, Jr, Billy Sunday Was his Real Name (Chicago: University of Chicago Press, 1955), 125 in Mead, The Lively Experiment: The Shaping of Christianity in America, 196. 
his theological studies in the home of Timothy Dwight. After completing his studies, Taylor accepted a position as minister of the First Congregational Church of New Haven, where he served for nearly ten years. In 1822 he returned to academic life, and took Dwight's chair in Didactic Theology, a position which he held until 1857 when ill health forced him to step down. ${ }^{37}$

Taylor created an amalgam of Calvinism and common-sense, which accounted for personal responsibility in the acceptance or rejection of evangelistic proclamation and even natural revelation. ${ }^{38}$ As his primary tool for adapting Reformed theology to the American situation, Taylor utilised his exposure to Scottish common-sense philosophy. ${ }^{39}$ In keeping with commonsense philosophy, Taylor had an optimistic view of human nature and a high regard for anthropology. ${ }^{40}$ His affirmation of freedom was exceedingly attractive to the society at large, which prized both political and social freedoms. ${ }^{41}$ From a purely aesthetic perspective, in Taylor's use of reason in theology and in preaching, we see parallels with the tight logic and utilitarian use of psychology so present in Thomas Reid's own writing. However, like Reid, central to Taylor's work was the belief that philosophy and theology were to be logical and commonly understood by all.

\section{The theology of Taylor}

We will examine below, the two main differences between Taylor and orthodox Calvinism, and illustrate how these departures represent the way in which Scottish common-sense philosophy was appropriated by Taylor to accommodate revivalism during his time in the Second Great Awakening.

37 Bruce M. Stephens, 'Nathaniel W. Taylor (1786-1858): On Speaking of the Trinity', Princeton Seminary Bulletin 66 (1973): 113-14.

38 This includes the human ability to observe and reason, which would ultimately enable all humans to discover the same truths that theologians could discover in the Bible. New Haven theologians asserted that all men and women could discover the existence of God purely by reason. Hirrel, Children of Wrath: New School Calvinism and Antebellum Reform, 35 .

39 'Nathaniel W. Taylor [was] the most original, powerful, and widely influential mind which New England theology ever possessed. Dwight [Taylor's mentor] had been familiar with English and Scotch philosophy, and the great master Reid, and had laid the foundation of the philosophy of common-sense, which Taylor adopted, and which became the great offensive weapon of New England apology as well as its great instrument of constructive reasoning.' Frank Hugh Foster, A Genetic History of the New England Theology (Chicago: The University of Chicago Press, 1907), 246.

40 David F. Wells, Reformed Theology in America: A History of its Modern Development (Grand Rapids: Eerdmans, 1985), 40.

${ }^{41}$ Hirrell, Children of Wrath: New School Calvinism and Antebellum Reform, 39. 
Election and predestination. Taylor believed that scriptural doctrines could not be ignored simply because they were difficult to understand; as is certainly the case with the doctrine of election and predestination. He believed that election, when understood properly, could be a doctrine which would benefit both the converted and the non-converted. ${ }^{42}$ This is curious, as traditional perspectives on election limit the scope of those benefiting from the doctrine to the elect and the Divine; leaving those predestined for damnation in the dark. In his lectures on Revealed Theology, Taylor offers three examples of what he thinks election is not: (1) It is not a national election of the people of Israel, or of any nation in particular; (2) it is not election to salvation; and lastly (3) election as not based on a condition of repentance (as is the case in the Armenian understanding of predestination on the basis of divine foreknowledge of human choice). ${ }^{43}$ Taylor builds his doctrine of election from three foundational principals: (1) Christ died for all people; (2) all will be saved if they repent and believe the gospel; and lastly (3) it is the will of God for all people to repent and believe, so that they may, "comply with the terms of life rather than continue in sin'. ${ }^{44}$ Taylor is clear that it is God's unconditional will for the whole of humankind to receive the benefits of salvation. ${ }^{45}$

Obviously Taylor's notion of election is markedly different than his predecessors, who would argue that God's offer of salvation through the propitiation of sin is limited in its availability to only the elect. ${ }^{46}$ In Taylor's thought, election and predestination is general and universal, and intimately connected with universal moral agency, which we shall see below becomes itself the vehicle of election.

42 According to Taylor, election is 'a doctrine of most salutary practical tendency; directly fitted to augment the power of other truths; adapted to sanctify, to strengthen, to comfort and perfect the saints and to rouse the sinner to instant, direct, and decisive effort in the work of his salvation'. Nathaniel William Taylor, Essays, Lectures Etc. Upon Select Topics in Revealed Theology, ed. Bruce Kuklick (New York: Garland, 1987), 373.

43 Taylor, Essays, Lectures Etc. Upon Select Topics in Revealed Theology, 374.

44 Taylor, Essays, Lectures Etc. Upon Select Topics in Revealed Theology, 375-6.

45 'God would that all men [sic], elect or non-elect, should turn and live, rather than sin and die.' Taylor, Essays, Lectures Etc. Upon Select Topics in Revealed Theology, 377.

46 Regarding the atonement, Taylor posits: 'God ... has made abundant provision for the salvation of every human being; that all will be saved if they comply with the terms of salvation... as free moral agents [all] can comply with these terms...' This view of a general atonement is so contrary to orthodox Calvinism, it is hard to see any semblance of Edwardsian influence at all! Taylor, Essays, Lectures Etc. Upon Select Topics in Revealed Theology, 389. 
Total depravity. Even though God may desire ${ }^{47}$ to save all (both elect and non-elect) there is still the nagging issue of the existence of sin and the problem of human wickedness. Indeed, theodicy is not simply pushed aside because of Taylor's innovative approach to election and predestination. Contrary to Calvinist orthodoxy, ${ }^{48}$ which understood 'sin [as] the necessary means of the greatest Good'49 (thus making the damnation of the non-elect an offering to the Glory of God), Taylor posited the following:

What kind of mercy ... produces evil merely for the sake of putting an end to it... does a benevolent God design and so order his providence that our whole race shall fall into the gulf of sin and ruin for the sake of showing his mercy in their rescue; and this when he could as well have preserved them and all other beings in the purity and joys of perfect holiness for ever... call this mercy, if you will, but oh, ascribe not such mercy to our God! $!^{50}$

Furthermore, in his famous sermon Concio ad Clerum, ${ }^{51}$ Taylor asserts that human depravity 'does not consist in any essential attribute or property of . . any thing created in man by his Maker'. To enforce this point, he asks the rhetorical question, 'Does God create in men [sic] a sinful nature and damn them for the very nature he creates? Believe this who can'.${ }^{52}$ For Taylor, moral depravity is not: (1) a propensity to sin in humankind's constitution; (2) an excitement or desire to sin; or (3) a disposition to sin which is caused by a first $\sin .^{53}$ Indeed, the thought that sinfulness is an inherited trait, is utterly reprehensible to Taylor.

47 Although Taylor is clearly a part of the rational theological tradition, and in direct line with the Scottish common-sense tradition, he does have certain romantic tendencies. For example, he emphasises the desire of God to save all, by illustrating the passion of God for the lost: 'yea with the compassion of a God; he desires, he longs that under the influence he uses, every sinner should repent and live, rather than sin another movement'. Taylor, Essays, Lectures Etc. Upon Select Topics in Revealed Theology, 378.

48 Taylor's position on the foolishness of moral depravity being the fault of the divine creation echoes the same sentiment in Reid, who agrees with Taylor that humankind is divinely given a moral sense that is the same as its maker. C. F. Reid, Lecture 78 in Duncan and Eakin, eds., On Natural Theology, 97.

49 Taylor, Essays, Lectures Etc. Upon Select Topics in Revealed Theology, 381.

50 Taylor, Essays, Lectures Etc. Upon Select Topics in Revealed Theology, 381.

51 Literally, 'Preaching to the Converted'

52 Nathaniel William Taylor, Concio ad Clerum: A Sermon on Human Nature and Freedom [on-line]; available from http://www.moody.edu/undergraduate/bibletheo/theo/Quiggle/ ge420/taylor.htm; accessed 28 February 2003.

53 Taylor, Concio ad Clerum: A Sermon on Human Nature and Freedom, Section 1. 
And what sort of philosophy, reason or common sense is this - a sin before the first $\sin -\sin$ before all sin? Do you say there must be difficulties in theology? I ask must there be nonsense in theology?'54

Moral agency and election. Sinfulness is not created by God in humanity nor is it inherited in humanity through the concept of original sin. For Taylor, sin is the responsibility of the sinner, and it is God's purpose 'to secure the holiness of as many of his moral creatures as it is possible'. But according to Taylor, God does so not through election of the individual, but through the establishment of a moral system and personal moral capacity. Herein lies the essential theme in New Haven theology: moral agency and moral government are a means of creating an environment that is conducive to the divine act of election; because positive moral agency is the means of election, all humanity (converted and non-converted) benefit from election. In contrast to his predecessor, Jonathon Edwards, Taylor does not believe that moral agency is a compromise between God's omnipotence and human freedom, rather according to Taylor:

Every subject of such a kingdom must be a free agent; i.e. he must possess the power to sin, and to continue to sin, in defiance of all that God can do to prevent him. If God destroys this power, he destroys his moral agency, and then even God cannot make him holy. ${ }^{55}$

God functions benevolently by electing moral agency as a system that allows all creatures to choose God or wickedness. God's benevolence is not found in the elimination of sin, but in the creation of a just system which allows for morally culpable beings to choose for, or against, God and the good. According to Taylor, it is the only and best means of accomplishing infinite goodness. He argues that if this system fails to bring the individual to salvation, the fault is not in the system but the individual. ${ }^{56}$

Taylor maintains that sinfulness is purely the result of humankind's own actions, which consist of a free choice of some other object than God or the good. Depravity for Taylor is the propensity to sin when the occasion arises. ${ }^{57}$ His belief that the individual can act contrary to the will of God

54 Taylor, Concio ad Clerum: A Sermon on Human Nature and Freedom, Section 1.

55 Taylor, Essays, Lectures Etc. Upon Select Topics in Revealed Theology, 382.

56 'It is no impeachment of a father's kindness that its results are impaired or prevented by the child's perverseness.' Rather, it is the human will which thwarts the divine plane. Taylor, Essays, Lectures Etc. Upon Select Topics in Revealed Theology, 385.

57 Taylor, Concio ad Clerum: A Sermon on Human Nature and Freedom, Section 2. 
in regards to personal salvation is perhaps Taylor's greatest departure from orthodox Calvinism. In his words, it is 'the sinfulness of the sinner [that] limits God's ability to bring him [sic] to repentance'. ${ }^{58}$ Incidentally, because for Taylor sinning is in the acting, unlike Calvin he asserts that newborns are free from the contamination of sin:

If then you ask, what becomes of an infant if he dies, while yet an infant? I answer, he may be saved; in my belief he is saved, through the redemption that is in Christ Jesus. If you ask, how can this be? I reply he belongs to a race who by nature, in all the circumstances of their immortal being without the grace of this redemption, will $\sin .{ }^{59}$

\section{A common-sense approach to Revivalism}

Because humans have the power to choose sin they also have the power to choose God (in the context of the preaching of the Christian Gospel). This means that preaching and evangelism become highly effective means of offering salvation. Taylor writes:

To what purpose do we preach the gospel to men, if we cannot reach the conscience with its charge of guilt and obligations to duty? And how I ask can this be done, unless sin and duty be shown to consist simply and wholly in acts and doings which are their own? ${ }^{60}$

Taylor argues that Christian proclamation (such as Edwards') which relied upon a presupposition of the election and predestination of individual hearers (in order for the message to be effectual), did not effectively communicate the gravity of human guilt for sin:

Will the charge of such sin on man, touch the secret place of tears? . . If so, preach it out - preach it consistently - preach nothing to contradict it dwell on your message, that God creates men sinners and damns them for being so... but such is not the message of wrath and of mercy, by which a revolted world is to be awed and allured back to its maker. The message we are to deliver to men [sic] is a message of wrath, because they are the perpetrators of the deed that deserves wrath. (emphasis mine) ${ }^{61}$

58 Taylor, Essays, Lectures Etc. Upon Select Topics in Revealed Theology, 387.

59 Taylor, Concio ad Clerum: A Sermon on Human Nature and Freedom, Remarks 1.

60 Taylor, Concio ad Clerum: A Sermon on Human Nature and Freedom, Remarks 5.

61 Taylor, Concio ad Clerum: A Sermon on Human Nature and Freedom, Remarks 5. 
Taylor's theology enabled one to preach the Gospel with the expectation that all who came forward could potentially benefit from the offer of divine grace. His view not only takes into account the practice of mass evangelistic preaching, but also engages the substantial response to such preaching by those claiming to have experienced some sort of conversion. I would argue that Taylor's adaptation of the doctrine election and predestination tacitly reflects a common-sense analysis of evangelism. In this respect, Taylor appears to be relying on two principles of common sense: (1) that history will remain constant and (2) that personal testimony is reliable. ${ }^{62}$ Taylor appears to make a theological accommodation to testimonies of conversion which would otherwise be considered suspect in light of strict Calvinist orthodoxy. The massive response to evangelism during Taylor's time could be understood in one of three ways:

1. that, in his time, evangelism was particularly fruitful because there existed a higher density of the elect among the general population than would normally have been the case;

2. that conversion experiences were indeed shared by both elect and nonelect, but that genuine conversions were only effectual for those who were among the elect, leaving the professing non-elect to their eternal damnation;

3. that there was a genuine conversion of all who responded to the evangelistic message, because all people are elect, and are free to respond to the message of salvation.

The first option, though possible, does not seem plausible in light of the common-sense principle that history will continue to function consistently. It begs the question, 'Why would God have a higher density of elect souls in nineteenth century antebellum America than were present at other periods of history?' The second option is completely untenable, in as much as it denies the common-sense principle which lauds the reliability of personal testimony. Besides, the very thought that one could profess to conversion, but have this confession be ineffectual because of their status as a nonelect person, is distasteful at best. Unlike the other two options, the third choice passes unscathed the critique of common-sense philosophy. It seems

62 In Reid's time, his use of the concept of 'testimony' was purely juridical, the underlying concept which depends upon the others truthful expression of personal experience, holds true as the shared dimension of the principle. Reid, 'Essays' VII 3.3 in Hamilton, ed., The Works of Thomas Reid, 1:482. 
most logical that those responding to the Christian message are doing so genuinely, and that their testimony to the fact reveals the underlying salvific work of Grace, apart from individual election. Therefore, if mass conversions were indeed efficacious apart from individual election, Calvinist orthodoxy would need to adhere to a more universal conception of election and predestination.

Taylor's concerns with Revivalism bled through into his portrayal of the Doctrine of God. For Taylor, God was constantly and passionately in pursuit of the lost by way of moral agency and natural revelation. Taylor described God as crying out from heaven, 'Believe on the Lord Jesus Christ ... my son, give me thine heart.' Through moral agency, the inner voice of humanity expresses to itself, 'every denunciation of wrath, heaven, earth, judgment, hell [calling the will to] Do it! Do it!' - in regards to accepting the divine offer of salvation. ${ }^{63}$ Taylor firmly believed that God gave humankind the capacity to completely turn away from sin, and turn to God - humanity are told to do so through the admonition of the will and the whole of the ordered world. ${ }^{64}$ In the spirit of revivalism Taylor urged his audience to, 'remember that if you do not begin, God will never convert you and if you delay little longer, there is a fearful probability that God will give you up to determined sin and final ruin'.65

For Taylor, because of the power of human choice, God was not responsible for the eschatological fate of individuals. Taylor states that 'in hell I am ruined, self ruined...'; $; 6$ no one is responsible for an individual's rejection of the divine gift except for that individual. Taylor was resigned to the fact that some would unfortunately turn away from the divine gift, and face ruin and eternal separation from God. He recognised that this was the horrible curse that came in tandem with the incredible gift of human freedom. According to Taylor, 'the doctrine of election, of man's free agency, of God's sincerity and the necessity of action on the part of sinners are true, and consistent truths. They are solemn and awful truths, too. ${ }^{67}$ For Taylor, it would be humankind's power to 'choose the contrary' with regards to God's gracious offer of salvation, which would constitute the end product of the divinely executed system of moral agency.

63 Taylor, Essays, Lectures Etc. Upon Select Topics in Revealed Theology, 398.

64 Taylor, Essays, Lectures Etc. Upon Select Topics in Revealed Theology, 400.

65 Taylor, Essays, Lectures Etc. Upon Select Topics in Revealed Theology, 406.

66 Taylor, Essays, Lectures Etc. Upon Select Topics in Revealed Theology, 388.

67 Taylor, Essays, Lectures Etc. Upon Select Topics in Revealed Theology, 424-5. 


\section{Early objections to Taylor}

As is often the case with innovations in theology, objections abounded ${ }^{68}$ (and abound) to Taylor and New Haven theology. ${ }^{69}$ Many likened New Haven theology to Pelagianism in the early church. Taylor's chief opponent, Charles Hodge, was a keen defender of Old School Calvinism and ${ }^{70}$ feared that Taylor's system would empty the significance of the work of Christ on the cross, leading to theological universalism. ${ }^{71}$ Furthermore, Hodge was particularly concerned about Taylor's understanding of humankind's ability to be indifferent to divine grace. In his Systematic Theology, Hodge condemns New Haven theology as being a

doctrine of contingency, which has been held under different names and variously modified. Sometimes it is called the liberty of indifferences, by which is meant, that the will at the moment of decision is self-posed to, among conflicting motives to decide one way or the other, not because of the greater influence of one motive over others, but because it is indifferent or undetermined, able to act in accordance with the weaker against the stronger motive or even without any motive at all... The advocates of this theory of liberty, therefore, maintain, that the will is independent of reason, of feeling, and of God. This is no middle ground, they say, between uncertainty and fatalism, between the independence of the will and the agent and the denial of all free agency. ${ }^{72}$

${ }^{68}$ Other extant scholars besides Hodge criticised Taylor's theology. Ebenezer Porter from Andover Seminary accused Taylor of questioning the 'old paths' and shedding darkness on the world. He also said that New Haven theology was essentially 'a channel of communication between Calvinism and Pelagianism.' Ebenezer Porter in Joseph Harvey, Letters on the Present State and Probable Results of Theological Speculations in Connecticut (no publication information), 27-28 in Wells, Reformed Theology in America: A History of its Modern Development, 40.

69 This conflict also manifested itself in a feud between Princeton and Yale, which in addition to being a theological and philosophical conflict, was also a political one which revolved around the question of who was to be considered the legitimate heir to the Jonathon Edwards' theological legacy. Yale, as the traditional home of Edwards, was threatened by Princeton whose divines considered themselves to be the rightful intellectual descendents of Edwards' orthodoxy.

70 Oddly, Hodge, this chief polemicist against Taylor and New Haven theology, was himself steeped in the same common-sense philosophy as Taylor, but implemented this philosophy in an utterly different way. Cf. Ahlstrom, 'The Scottish Philosophy and American Theology', 266.

71 Wells, Reformed Theology in America: A History of its Modern Development, 46.

72 Hodge's view betrays his pessimistic understanding of moral agency, and describes a God who is unwilling to allow his creation to have any freedom. Charles Hodge, Systematic Theology (London: James Clarke, 1960), 2:282-4. 
Further objection to New Haven theology came in 1853 when James Wood (an Old School Presbyterian) addressed the 'settlements' of New Haven theology, with regards to the 'theories of the mind, of free agency, and of moral government... introduced by the new philosophy'. Like Hodge, Wood expressed concern over Taylor's belief in humankind's ability to choose sinfulness or grace, and to the 'settlements' (accommodations) that this theology made to experiential piety. His conclusion was that these 'philosophies' were not new, but originated 'long ago as in the time of Pelagius and they have sprung up and flourished for a while at different periods since'. ${ }^{73}$ The philosophy which Wood refers to is undoubtedly the Scottish common-sense philosophy, which like the theology of New Haven, and the theology of Pelagius in the fourth and fifth centuries, offered an elevated role of human capacity to choose the good.

Even in the present day, orthodox Calvinists continue to debate about New Haven theology. The American Presbyterian Church sees ‘Taylorism' as a 'third step' from orthodoxy, which will ultimately lead to Unitarianism. They understand Taylor's 'New Divinity' as a corruption of orthodoxy and an attempt at usurping 'the orthodox Calvinistic theology of the New England puritans' which they believe may eventually result in 'full blown Pelagianism'. ${ }^{74}$ The Old School/New School Calvinist debate is also a feature in contemporary contention between American Congregationalists and the Presbyterian Church (USA).

Taylor's legacy in Revivalism. Slander and dissent aside, Taylor's adaptation of Calvinist Orthodoxy did find a surprising extant proponent in the nineteenth century. Charles Finney (1792-1875), the so called father of modern-day Revivalism, appropriated Taylor's belief in personal conversion into his own theological cache. Before Finney had moved from Presbyterianism to Methodism, he read and admired the work of Taylor and the New Haven divines, asserting that "Taylor was correct: humans do have within themselves the power for choosing Christ and living holy lives. ${ }^{75}$ Finney's 'New Measures' adopted New Haven theology, and represented a shift in evangelistic practices which emphasised the role of human choice

73 James Woods, The Doctrinal Differences which have Agitated and Divided the Presbyterian Church: or Old and New Theology (Philadelphia: Presbyterian Board of Publication, 1853), 20.

74 American Presbyterian Church, 'The New Divinity', Presbyterian History [on-line]; available from http://www.americanpresbyterianchurch.org/the_new_divinity.htm; accessed 28 February 2003.

75 Charles Finney in Noll, A History of Christianity in the United States and Canada, 235. 
in the process of salvation. Finney's belief in the 'free enterprise of religion' seems to have borrowed from Taylor's universal 'moral agents'. 76

\section{Conclusion}

Taylor and his Yale cohorts established a theological system that provided a sensible interpretation of orthodox Calvinism in the face of the experience of revivalism in his day. New Haven theology adapted to trends in religious and pietistic life, as well as the assault upon orthodoxy by Unitarians and Deists, by employing the common-sense philosophy of the Old World, to the distinctly New World religious landscape. In so doing, Taylor echoed Reid's positive optimism regarding the human condition and human moral capacity, while still retaining a sense of humankind's ultimate dependence on God's grace for the capacity to choose Christ. Furthermore, Taylor's defence of the efficacy of individual conversions during mass evangelism, revealed an underlying foundation in Scottish common-sense principals, which lauded the human capacity to know and judge the world through the senses. Taylor's theology, though significantly different from Calvin or even Edwards, made a form of Calvinism applicable to the religious landscape of antebellum America. $^{77}$

\section{Bibliography}

Ahlstrom, Sydney. 'The Scottish Philosophy and American Theology', Church History 24 (1955): 257-72.

American Presbyterian Church. 'The New Divinity', Presbyterian History [on-line]; available from http://www.americanpresbyterianchurch.org/the_new_divinity.htm; accessed 28 February 2003.

76 Indeed, it would seem that Finney's choice of words reflect another incidental Scottish connection - Adam Smith, the founder of modern capitalism and the free market system.

77 On a personal note, I have always found the nature of Taylor's writing to be very refreshing. His struggle between experience and theology is one that all theologians encounter at some point in their life of faith. Faith is filled with paradoxes where our beliefs and our experiences need to be able to interpenetrate each other. His writing reveals a very sincere investigation into alternatives to his theological history. At the end of the day, the tension, which he illustrates, is an overarching debate in Christian history between the power of God and the power of humankind in controlling human destiny and salvation. Even today, 'Open Theists', such as Clark Pinnock, struggle with explaining logical alternatives to orthodox Calvinism. Furthermore, Reid's expression of a philosophical tradition which gave credence to our lived life and experiences, is a system which deserves more credit and attention in our contemporary context. 
Calvin, John. Institutes of the Christian Religion [on-line]; available from http://www. smartlink.net/ douglas/calvin/; accessed 28 February 2003.

Cherry, Conrad. 'Nature and the Republic: The New Haven theology', The New England Quaterly 51 (1978): 509-26.

Duncan, Elmer H. and Eakin, William R. eds. Thomas Reid's Lectures on Natural Theology (1780). Washington, DC: University Press of America, 1981.

Elwell, Walter A., ed. Evangelical Dictionary of Theology. New York: Baker Book House, 1984.

Foster, Frank Hugh. A Genetic History of the New England Theology. Chicago: University of Chicago Press, 1907.

Hamilton, Sir William, ed. The Works of Thomas Reid. 1. Edinburgh: Maclachlan and Stewart, 1863.

Hamilton, Sir William, ed. The Works of Thomas Reid. 2. Bristol: Thoemmes Press, 1999.

Hirrel, Leo P. Children of Wrath: New School Calvinism and Antebellum Reform. Lexington: University Press of Kentucky, 1998.

Hodge, Charles. Systematic Theology. London: James Clarke, 1960.

Houston, Joseph. Thomas Reid. Aberdeen: Handsel, 2000.

Mead, Sidney E. The Lively Experiment: The Shaping of Christianity in America. London: Harper \& Row, 1976.

Noll, Mark A. A History of Christianity in the United States and Canada. Grand Rapids, MI: William B. Eerdmans Publishing Company, 1992.

Stephens, Bruce M. 'Nathaniel W. Taylor (1786-1858): On Speaking of the Trinity', The Princeton Seminary Bulletin 66 (1973): 113-19.

Taylor, Nathaniel William. Concio ad Clerum: A Sermon on Human Nature and Freedom [on-line]; available from http://www.moody.edu/undergraduate/bibletheo/ theo/Quiggle/ge420/taylor.htm; accessed 28 February 2003.

Taylor, Nathaniel William. Essays, Lectures Etc. Upon Select Topics in Revealed Theology. New York: Garland, 1987.

Wells, David F. Reformed Theology in America: A History of its Modern Development. Grand Rapids, MI: Eerdmans, 1985.

Woods, James ed. The Doctrinal Differences Which Have Agitated and Divided the Presbyterian Church: Or Old and New Theology. Philadelphia: Presbyterian Board of Publication, 1853. 